\title{
A REVIEW OF ASSESSMENT POLICIES IN SUSTAINING CULTURAL IDENTITY INTO NEW ARCHITECTURE
}

\author{
Linda Shafarina Hassan*1, Yahaya Ahmad ${ }^{1}$, Brit Anak Kayan', Mohd Rizal Zakaria² \\ ${ }^{1}$ Department of Architecture, Faculty of Built Environment, Universiti Malaya (UM),Kuala Lumpur, Malaysia \\ ${ }^{2}$ Infrastructure University Kuala Lumpur (IUKL), Kajang, Malaysia \\ E-mail: *linda.s@siswa.um.edu.my
}

\begin{abstract}
Assessment tool is widely used as an efficient scheme to guide and control minimum design acceptance in improvising design issues of architecture. However, the current assessment tools in built environment might impose culture risks because they are limited to global sustainable architecture concept and not signifying local cultural principle. Limited attention has been paid to develop an efficient scheme to preserve cultural image and identity into a new development. Meanwhile, new architecture is the most potent agent to the lack of local culture of a place. The current architecture trends have been rapidly increasing worldwide, transforming the image of cultural context into a global city. This scenario might impose heritage risk if the current redevelopment planning scheme does not provide adequate guidance for sustaining cultural image and identity in new developments. The aim of this paper is to improvise the policy control on the image of future residential development in Kampong Bharu as the village is currently critical with heritage risk scenario due to the redevelopment issue. This study begins with a critical literature review on the efficiency matter of the current international policies from the perspective of preservation polices and new architecture policies. Interviews were conducted to appraise the appropriateness of the national polices in relation to the research issue. The results from literature reviews and interviews were used to form a summary of general components and elements which are missing from the existing polices. The main research output recommends a new concept of assessment with related components and elements in developing an assessment framework as a strategy to improvise the efficiency of assessment onto architectural cultural identity.
\end{abstract}

Keywords : Assessment policy, Cultural Identity, New Architecture

\section{INTRODUCTION}

The global issue of architectural image and identity crisis in the twenty-first century seemingly commenced with the critique against the new architecture image brought by the previous century. One of the earlier scholars, Marinetti (1909) (cited by J.Ostwald \& Fleming, 2000), interpreted that new architecture tends to swipe cultural image and identity away due to aggressive image of expressing the power of modern technology, importance of science, and political power. Some of the new architecture movements are found disastrous as they introduce a barrier between old architecture approach and the modern world (Stern, 1988; Jencks, 1990). The discussion on architecture image and identity crisis has continued until today as few scholars have been supporting the fact that many inharmonic and insensitive developments are found in heritage context (Alderson, 2006; Delanty \& Jones, 2002; Hosseini, Mursib, \& Shahedi, 2011; Ibrahim, 2016; Khalaf, 2015; Misırlısoy, 2017). Such progress has been thought to impose heritage risk when the current trend of architecture design leads to deficiencies in sustaining cultural image and identity. Concerns have increased as to whether the current assessment policy has been effective in sustaining the cultural identity of architecture. The use of the BEA tools for evaluating the design value of sustainable concept in new architecture has received positive feedback by scholars, and as such, curiosity has increased on the components offered by the tool compared to the efficient issue in preservation policy.

This paper focuses on the issue of redevelopment policy strategy in sustaining the architectural cultural identity of Kampong Bharu, Kuala Lumpur. Scholars and media have justified their concern of the need to 
preserve the cultural identity for Kampong Bharu redevelopment due to the area's heritage significance and redevelopment issues. This paper thus reviews the related existing international and national assessment policies responding to the issue of sustaining cultural identity in new architecture. The attempt is to provide answers for the following question: Are these current preservation cultural architecture assessment policies sufficient in minimizing the negative impact of redevelopments towards the cultural identity in new architecture?

The paper is structured as follows. Section 2 describes the heritage background of Kampong Bharu and reviews the national policies related to its development policy. Section 3 reviews the efficiency issue of the current international preservation policies for new developments in cultural context at international level. Section 4 compares the general components and features offered in the BEA tools with the preservation policies. Section 5 analyses the expert reviewers' views on the national policies, and the lessons learned are concluded in the final chapter.

\subsection{Case Study: Issue of Architecture Cultural Identity in Kampong Bharu}

Malaysia is not excluded from the trend of eliminating cultural image and identity in architecture due to the many current building developments prominent at projecting the image of new architectural style, namely contemporary architecture. This new architecture style has received concerns by few scholars and local institution because the trend might risk the loss of local architectural image and identity to the local culture (Julaihi Wahid, 2000; Moser, 2012; Rasdi, 2011; Shamsul, 1996; Surat et al., 2010a, 2010b; Wolf, 2016). To mitigate this issue, two draft policies at national level were established, namely the (i) National Architectural Identity (NAIP) Draft Policy and the (ii) Guideline of Malay-Islamic Architecture for Kampong Bharu (MIAKB).

NAIP has been published in December 2016 by Board of Architects Malaysia (BAM), a statutory authority responsible for the enforcement of regulations related to architects' scope of work in Malaysia. The NAIP draft policy has been serving as a general framework to guide future policy developments associated to the regulation in National Heritage Act 2005 (NHA). Unlike MIAKB, NAIP is designed for a broad scope of future preservation developments, including architectural heritage, natural heritage, heritage education, and urban heritage. MIAKB, on the other hand, is a policy prepared by Perbadanan Pembangunan Kampong Bharu (PPKB), a government institution established to resolve the redevelopment issues of significant cultural context, Kampong Bharu specifically. In order to see the appropriateness of MIAKB in sustaining the cultural identity, a comprehensive review of the heritage background and redevelopment issue of Kampong Bharu was conducted.

\subsection{Heritage Background}

Formed by the British government in 1899, Kampong Bharu originally spanned 221.5 acres of land. The village is recognized as one of the Malay-Reserved Areas (MRA) in Kuala Lumpur. MRA was the initial idea of Tengku Ampuan Mahanom, the wife of Sultan Sulaiman Shah, Crown Prince of Selangor, before the matter was raised for an agreement discussion with the British government ( Suleiman, 1999). The idea of MRA was to ensure that the Malays would be able to have their own settlement after a large number of Chinese immigrants bought some land in Kuala Lumpur (DBKL, 2000; Harold, Abdul Samad, \& Zaharah, 2012). Thus MRA was formed under Federated Malay States Reservation Enactment 1913, currently known as The Enactment of MRA 1913, to protect Malay rights in having their own land in the future (Salleh Buang, 2007). Unlike the other five Malayreserved areas (Datok Keramat, Bukit Segambut, Sungai Penchala, Gombak, and Selayang), Kampong Bharu is the oldest MRA in Kuala Lumpur located at the north city center, enclosed by few main roads in Kuala Lumpur (Jalan Raja Muda Abdul Aziz, Jalan Tun Razak, Jalan Dang Wangi, Kelang River, and Jalan Tunku Abdul Rahman). This strategic location with the shortest distance to the centre of Kuala Lumpur offered better working opportunity and economic source, compared to other MRAs (DBKL, 2000; "Putting the New into Kampong Bharu," 2004).

However, Kampong Bharu has managed to escape from major developments for more than a century. Escaping from major developments has provide poor image effect of Malay identity and unaccepted Malay Identity in cultural context (Alhabshi Sharifah Mariam, 2010). 


\subsection{Redevelopment Issue of Kampong Bharu}

Previous studies have revealed two critical development issues in Kampong Bharu that are related to the cultural identity evaded from significant development. The critical issues are (i) high population of local residents, inheritance, and new comers; and (ii) inappropriate and unplanned physical development by individual (Samsor Junet, 2004; Wan Hazmir, Norfatimah, Sharifah Salwa, \& Faizatul Farlin, 2004).

The problem of high population and small area of land parcel has restricted a land owner's from upgrading his or her social needs, for example, from adding floor area to support the growth of family members (Suleiman, 1999; Wan Hazmir et al., 2004) The prolonged situation of no major development has caused major issues of big numbers of inheritance for each land parcel. Meanwhile, the small parcel refers to the earlier land status of Kampong Bharu, which was intended for agricultural settlement. The highest numbers of heritance for one parcel is 208 people, while there is a total of 1,193 land parcel with the size of 0.27 acre or less (APUDG, 2014) Economy constraints and size of lot have resulted in the upgraded homes presenting unacceptable image and poor condition for some of the residents and inheritance (Tim, 1986). Residents and the inheritance, especially from the middle- and high-income group, choose to leave the settlement and stay in a better living environment. This has caused low rentals and consequently a total of $49.7 \%$ of new residents in Kampong Bharu (Alhabshi Sharifah Mariam, 2010; APUDG, 2014). Most of these new residents are migrants who chose Kampong Bharu to fulfill their basic needs in starting a new life in Kuala Lumpur (APUDG, 2014). Studies have revealed that the increased number of illegal immigrants has neglected to serve the needs of the community, resulting in the loss of physical and social cohesion towards the cultural identity in Kampong Bharu (Alhabshi Sharifah Mariam, 2010). The constricted pathway and unorganized property development by individual due to high population has also brought Kampong Bharu into a chaotic traffic and congested area.

Later, Kampong Bharu Comprehensive Master Plan (KBMP 2014) was launched in April 2014 as a new redevelopment plan to replace the previous development strategy. The KBMP was prepared by Perbadanan Pembangunan Kampong Bharu (PKB), a new institution established by the goverment in 2011 as the main planner to control and supervise matters related to the redevelopment process in Kampong Bharu. KBMP was later presented with a detailed design guideline, namely Malay Islamic Architecture for Kampong Bharu (MIAKB), for the designing of appropriate image of future buildings in Kampong Bharu in presenting Malay Islamic features for contemporary architecture. Contemporary architecture was considered for its advantage of using new materials and technology, despite the traditional design approach being perceived as no longer appropriate in responding to the design constraints in Kampong Bharu (APUDG, 2014; Nik, 2014).

Unlike NAIP and KSP 2020, KBMP and MIAKB present an improvised clear guideline, divided into two categories of design, namely zoning and layout, and form. Both plans integrate Malay features into four types of building development: residential, commercial, mixed development, and institution. Contents of the policies are summarized based on the findings from numerous focus group discussions attended by professionals, academicians, and local community. KBMP particularly has adopted a new strategy by awarding an allowance of a plot ratio of 1:10 for new development for residents, which agrees to lot amalgamation (APUDG, 2014; Ujang, 2016). This strategy has received positive feedback in that residents from 87 lots have agreed to lot amalgamation (Council PPKB, 2014).

However, there is a growing concern that the allowance of a plot ratio of 1:10 might pose a challenge in sustaining the cultural identity of non-landed buildings. The TMH offers an open concept design and is ground friendly, yet limited studies have attempted to integrate the design principle of TMH into both contemporary landed and non-landed unit due to the current design constraints in architecture field.

\subsection{Issues with the Houses in Kampong Bharu}

Despite the criticism on the poor surrounding of Kampong Bharu, the village is among the unique places in Kuala Lumpur because it locates several old, traditional Malay houses (Chester, 2017; Jarod, 2015). Kampong Bharu has long become a spot for tourists, researchers, and film makers who seek a location that reflects the authenticity of the Malay image (Mari Anna Fujita, 2010; Ujang, 2012, 2016). A traditional Malay house is known as a gratified symbol of Malay culture due to its outstanding design principle that corresponds to tropical climate and Malay cultural life style (Abdul Rahman, 1999; Hosseini, Mursib, \& Shahedi, 2012; Yuan, 2002). The current 
TMHs in Kampong Bharu are found distinctive for their outstanding ability to stand still from rapid urbanization for more than a decade. Figure 1 shows some of the traditional Malay houses in Kampong Bharu that sit amid the background of prominent sky scrapers in Kuala Lumpur.
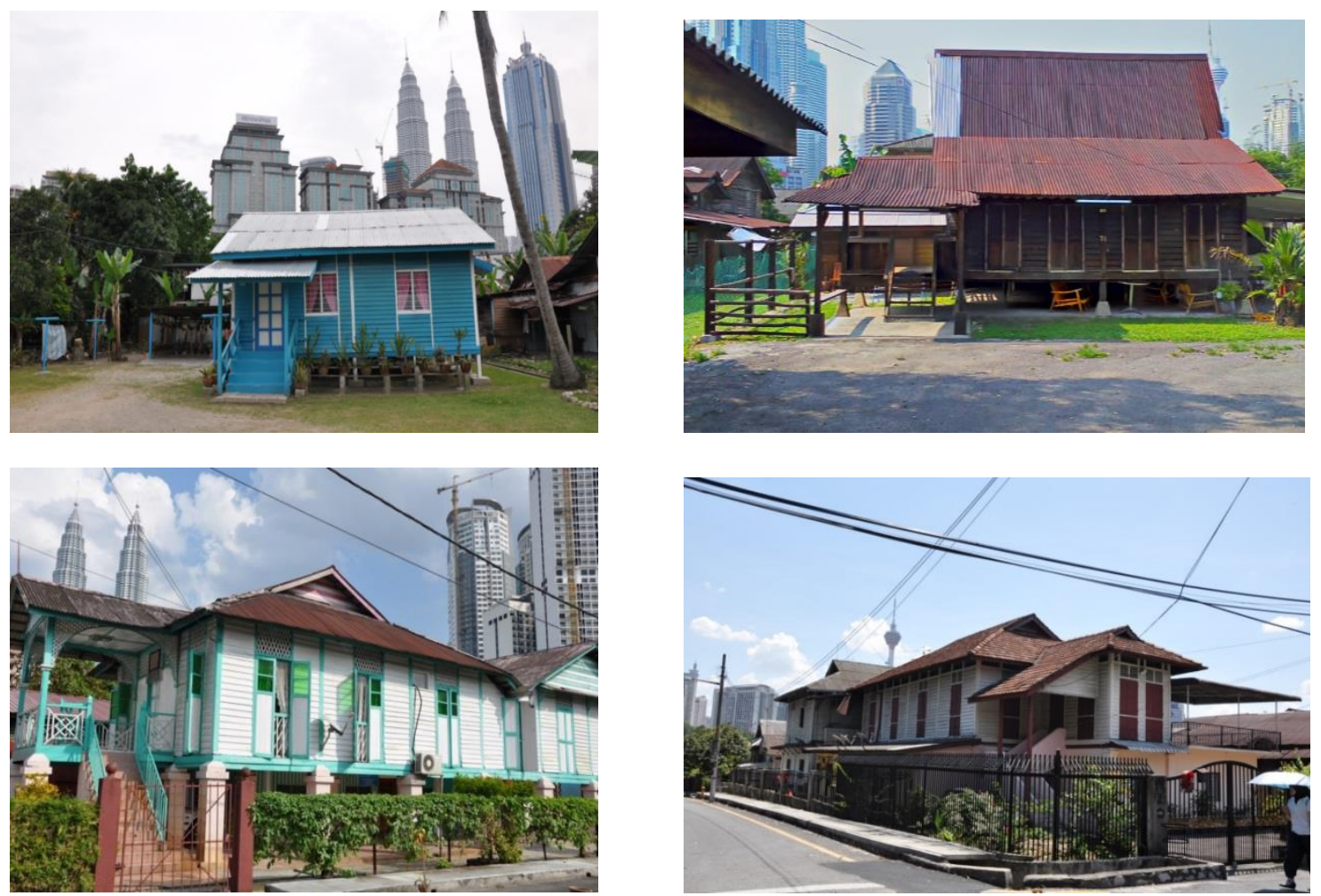

Figure 1: Some of Traditional Malay Houses in Kampong Bharu with the background of high profile building in Kuala Lumpur.

However, due to development pressure, some of TMHs were found removed from its original location. Study by PPKB has reported that on the 221.5 acre of land of Kampong Bharu, only 121 buildings manifest Malay architecture features. These buildings are residential houses located on individual land parcel, whereas the remaining 1200 land parcels were replaced with new buildings that reflect the influence of affordable material and technology typically used in the twenty-first century (APUDG, 2014; Ju, Omar, \& Ko, 2012) Unlike vernacular Malay houses which feature a modern-styled TMH, other building images in Kampong Bharu have shown poor physical development and a typical global image based on the growth of squatters and non-landed buildings. This development trend has exposed Kampong Bharu to heritage risk due to the current architectural growth, which has relinquished the village's original cultural identity. Figure 2 shows the poor physical image of squatters and the typical global image of the new buildings in Kampong Bharu.
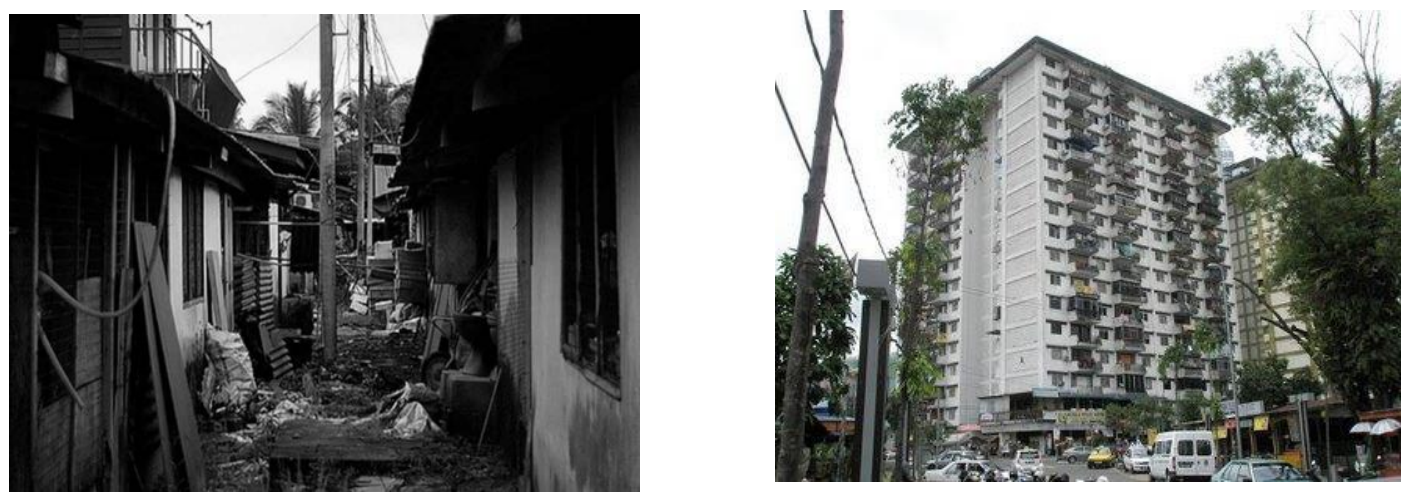

Figure 2: Poor physical image of squatters and typical global image of new building in Kampong Bharu 
The residential condition of Kampong Bharu also worsened after two major fire tragedies (Figure 3). The first tragedy occurred on 15 December 2014 when two rows of squatters in Jalan Raja Alang caught fire and resulted in the relocation of 96 people (Joibi, 2014) The second fire took down fifteen squatters at Jalan Raja Muda Musa on 29 December 2017 (Bernama, 2017).

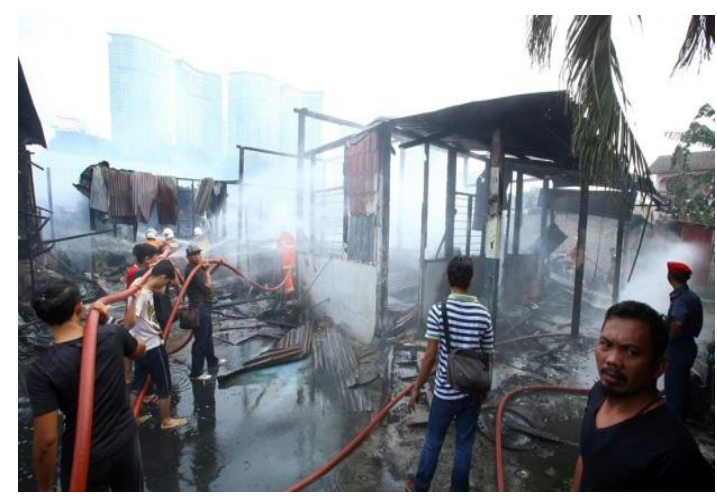

a)15 Squatters in Jalan Raja Muda Musa, Kampong Bharu was burnt in Fire

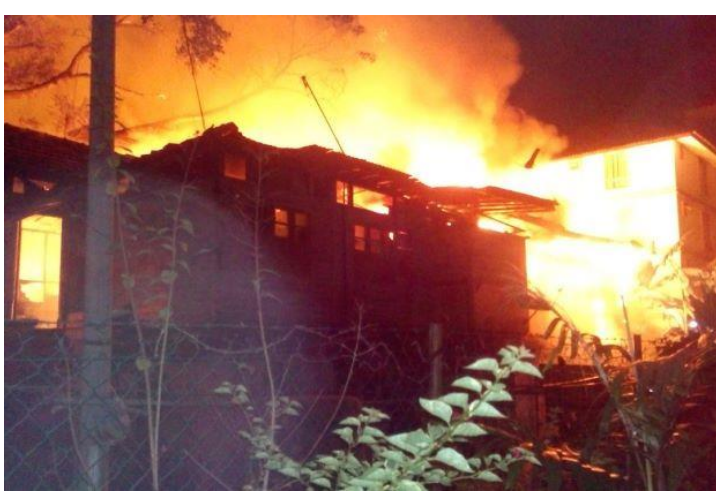

b) Two rows of squatters in Jalan Raja Alang,Kampong Bharu were burnt in fire

Figure 3: 2 Fire tragedies occurred in Kampong Bharu. Source: The Star Online 2014 and The Sun Daily 2017

The development issues in Kampong Bharu have supported the notions of pressures that are particularly alarming at notable cultural context: Kampong Bharu is losing its cultural image and identity.

\subsection{International Preservation Policies}

A few charters have been established to serve as international standards for the preservation of cultural image and identity in a new development. The charters are Safeguarding and Contemporary Role of Historic Areas (1976), the Washington Charter (1987), the Vienna Memorandum (2005), and the Recommendation on the Historic Urban Landscape (2011). The key preservation framework from these international charters have been used to develop several national guidelines (Imam, 2013), such as (i) Building in Context: New Development in Historic Areas in England (Golding, 2001), (ii) Design in Context: Guidelines for Infill Development in Historic Environments in New South Wales (NSW) Australia (NSW Heritage Office \& RAIA NSW Chapter, 2005), and (iii) Standards and Guidelines for the Conservation of Historic Places in Canada(2010). The establishment of these guidelines has introduced inconsistency due to minor alterations made to suit the local ideologies of outstanding universal value (OUV) and the requirements of building regulations. However, according to Khalaf (2015), these international charters and national guidelines share the same framework structures in that all lack an efficient parameter to guide the minimum acceptance of changes or to recommend a harmony interpretation in historic places. The guidelines particularly outline sole criterion and indicator which are inadequate to be called a measurement tool(Khalil, 2013; Nguyen, 2011; Nguyen \& Altan, 2011) This shortcoming has unfavorable implications on the image of many new developments as they were found inharmonic and insensitive with heritage context (Sotoudeh \& Abdullah, 2013; Tweed \& Sutherland, 2007).

Due to the need for a framework for developing a measurement tool for evaluating the cultural identity of a new development, ICOMOS introduced the "Heritage Impact Assessment" (HIA) framework as a strategy (i) to evaluate heritage impact towards Outstanding Universal Value (OUV) of heritage properties and (ii) to generate overall design grading upon new development in cultural context. This framework has been adopted by a few heritage institutions at district and state levels with some changes made to refine the process and method in interpreting the criteria of OUV in order to suit the local character (Cadw, 2017; Committee \& on Environmental and Occupational Health, 2010; NZTA, 2015; The Government of the Hong Kong Special Administrative Region, 2009; Incorporated George Town World Heritage, 2012).

However, limited studies have investigated the appropriateness of the recommended measurement scale by HIA to meet the changes of general criteria and indicators to adopt local context needs. There is also a concern on the reliability of the assessment methodology of HIA ICOMOS; it has been suggested that the tool should present a method to present a comprehensive view of subject value and balance the weighting among criteria and 
indicators (Kamaruzzaman, Nawawi, Husin, \& Hashim, 2015; Mcgill, Oyedele, Mcallister, \& Qin, 2015). Unlike the assessment methodology by established measurement tools, the current HIA frameworks are lacking in terms of criteria weighting, which plays a vital role of highlighting priority between criteria (Khalil, 2013; Khalil et al., 2015). This shortcoming might affect the decision making by professional and correlated actors in reviewing the priorities of the design features and its value (Nguyen \& Altan, 2011). Therefore, the recommendation of HIA as an efficient framework may not be justified.

One of the challenges to maximize the efficiency is by (i) refining the local cultural values in new architecture and (ii) recommending a capable assessment methodology to measure the explicitness of all related cultural values in the twenty-first century (Hosseini et al., 2011; Imam, 2013; Saradj, 2015; Steven W. Semes \& Chair, 2007). The perception of architecture value has also made the process of evaluating become tougher due to dissimilar interpretations, affected individual interest and need (Arheim, 1969; Do-kyoung Kim, 2006; Jencks, 1987; Stern, 1988; Winters, 1937). From the interpretation of several scholars (Chandler, 2007; Gunlu, Prrnar, \& Yagc1, 2009; Khalaf, 2015; Pichedpan, 2011; Ryberg-Webster \& Kinahan, 2013; Tomaselli, 2009), two studies are recommended to give positive impact on the efficiency issue in measuring new architecture value from cultural perspective. Further knowledge is required on (i) the effectiveness and deficiencies of the way cultural element been designed in new building and (ii) the boundary acceptance of missing cultural element in new building. Many of the existing studies in the field have focused on the interpretation of the cultural and identity, significance of cultural criteria, framework of conservation management, and heritage impact from new development (Agency, 2014; Khalaf, 2015; Nezhad, Eshrati, Eshrati, \& Design, 2015; Silva; \& Roders, 2011; (Ettehad, Azeri, \& Kari, 2014). Although these studies give added values to the significance of sustaining cultural identity, they offer limited ideas to enhance the assessment methodology in improvising the efficiency issue accordingly.

\subsection{The BEA Tools}

Another tool called the Built Environment Assessment (BEA) tool is an adequate example of an efficient assessment framework that is widely used to evaluate the performance of sustainable architecture concept based on specific criteria (Nguyen, 2011). More than four-hundred Built Environment Assessment (BEA) tools exist worldwide to serve as design guidelines (Nguyen, 2011). The tools provide weighing for listed criteria, thus enabling the evaluation of the extent to which a building design achieves standard design expectations (Adegbile, 2013). Professionals are increasingly looking at the design guidelines delivered by the BEA tools to achieve sustainability assessment recognition (Lasalle, 2008). One of the significant features found in a BEA tool is a set of components that deliver the credibility of measuring an item from subjective interpretation into a specific value. Table 1 shows the components and their respective functions in a BEA tool.

Table 1: The set of components and its function used in BEA tools

\begin{tabular}{|c|c|c|}
\hline BEA Tool's components & Definition and function & \multirow{5}{*}{$\begin{array}{c}\text { Authors } \\
\text { (Blyth, Gilby, \& } \\
\text { Barlex, 2006; Khalil et } \\
\text { al., 2015; Sadler \& } \\
\text { Sadler, 2010; Yue, } \\
\text { Briand, \& Labiche, } \\
\text { 2011, Ali \& Al, 2009; } \\
\text { Chen, Yang, \& Lu, } \\
\text { 2015; Fowler \& } \\
\text { Rauch, 2006; Lasalle, } \\
\text { 2008; B. K. Nguyen, } \\
\text { 2011; B. K. Nguyen \& } \\
\text { Altan, 2011; Reed et } \\
\text { al., 2009 }\end{array}$} \\
\hline Criteria & $\begin{array}{l}\text { As the general important items formed based on } \\
\text { the necessity of the subject discussed }\end{array}$ & \\
\hline Indicator & $\begin{array}{l}\text { Is a non-measurable key with specific } \\
\text { features to distinguish established criteria }\end{array}$ & \\
\hline Weighting & $\begin{array}{l}\text { Percentage or Ratio allocated for criteria and } \\
\text { indicator. }\end{array}$ & \\
\hline Ranking Scale & Classification level of total available points. & \\
\hline
\end{tabular}

The review is usually related to the target of the assessment tool, assessment boundaries of criteria and indicator, and weighting balance of the criteria. Based on this discussion, the credibility of an assessment tool framework is basically expressed by its assessment methodology in achieving the target of the tool. Assessment methodology is important at generating reliable result because it presents a comprehensive view of subject value and balanced weighting among the criteria and indicators (Khalil et al., 2015; Mcgill et al., 2015). Meanwhile, 
non-measurable keys with specific features of the indicator allow the describing of the reputable criteria in prioritizing a product or requirement (Ali \& Al, 2009; Chen, Yang, \& Lu, 2015; Fowler \& Rauch, 2006; Lasalle, 2008; Nguyen, 2011; Nguyen \& Altan, 2011; Reed, Bilos, \& Wilkinson, 2009). A grading scale is a parameter to distinguish the quality of indicator score and final score based on the aim of an assessment tool. The scale provides a minimum acceptance score and recommends an outstanding score for maximum result. The parameters scales that are usually used to evaluate indicator scores are Thurstone scale and Likert scale. The Thurstone scale is used as a non-score indicator or a scored indicator that provides specific grading weightage, such as 0 or 1,0 or 2,0 or 3,0 or 4,0 or 5,0 or 6,0 or 8 . The Likert scale, on the other hand, provides a wider range of grading weighting in evaluating the quality features of the scored indicator. Example of a Likert-scale grading for indicator are 1-3, 15, and 1-10. A parameter scale, which is used to evaluate the final score of an architecture value, is usually presented in a Likert scale with an interval range of four (4) to six (6) score levels (Nguyen \& Altan, 2011).

The above notion has proven that the BEA tools are widely used because the parameters features provide a specific design value in interpreting the details of the indicators. These parameters features have been used for many years and are common in planning an economics rating system (Nguyen, 2011) The indicators in the BEA tool have been finely monitored and can be used to facilitate reporting the outcome of a measurement scheme. Therefore, this adequate system was adopted in many built environment national policies for guiding new architecture designs to implement sustainable development (Khalil, 2013). By looking at the proficiency of the assessment methodology by the BEA tools and the current research gap in preservation policy, we can clearly see that the current preservation policies lack a refined assessment methodology to evaluate the score of every indicator thus leading to the gap in evaluating the efficiency of a design and in minimizing the heritage risk as mentioned by Khalaf (2015). Compared to the new architecture field, the current design guidelines of cultural context are underdeveloped and need to be improvised.

However, the BEA assessment framework does not signify a local cultural principle that might impose heritage risk to an architectural culture identity. Most of the previous studies related to BEA tool primarily focus on energy efficiency issues, climate of local context, indoor air quality, passive design approach, risk mitigation, materials and new technology, and sustainability design constraint (Baird, 2015; Borg, Borg, \& Thesis, 2001; Council, 2013; K.C.Ding, 2008; Mcgill et al., 2015; Nikolaou, Kolokotsa, \& Stavrakakis, 2015; Shaawat \& Jamil, 2014; Sharifi, 2013; Wallbaum, Ostermeyer, Salzer, \& Escamilla, 2012). Thus despite the exhaustive list of criteria and indicators, adopting the BEA tool might only be limited to using the parameter scale to evaluate the indicator score and final score for the redevelopment of sustaining a cultural identity.

\section{METHODOLOGY}

\section{Expert reviews on national assessment policies}

Limited research is found in appraising the appropriateness of the two national policies, as mentioned in section 2, in responding to the issue of architectural image and identity in Malaysia. Therefore, expert interview were conducted to investigate the efficiency of the two policies in order to control the image of new development in sustaining the local identity of architecture in Kampong Bharu. In order to have in-depth review against national policies, focus group technique was used as it provides high reliability compared to individual method (Harrell \& Bradley, 2009). This is due to focus group generating discussion outcomes. It also provides flexibility in choosing respondents as the method does not require a study of total population (Creswell, 2007).

According to previous researchers, it is advisable that the total of respondents for focus group discussion has a minimum of three participants (Tobias, Kerrie, Christina, \& Nibedita, 2018). Meanwhile Kamberelis \& Dimitriadis (2005), mentioned that two to five are usually used for participants with a high level of expertise.

Since the research focuses on the review of assessment policies in sustaining cultural identity, it is crucial to acquire respondents who possess knowledge of international and local preservation policies. Generally, the selection of respondents is based on their significant roles and knowledge contribution as international player and local player in the field of conservation architecture.

However with the criteria selection, there are only 2 local experts which have been found adequate to give a significant review towards the discussion: 1) having industry experience in conservation architecture at local and 
international level, 2) possesses knowledge of theories in conservation architecture, 3) has a minimum 30 years working experience in industry and academic.

Few questioned were asked to the conservation architecture experts during this preliminary study to investigate the appropriateness of these policies towards the recommended theory by Ryberg-Webster and Kinahan (2013).

Question 1: Do you think current policy has refined the effectiveness and deficiencies of having cultural element in new building and the way it has been designed?

Question 2: Do you think current policy provide boundary acceptance of missing cultural element in new building

Finding from the interviews indicated that the 2 (two) policy designs lack significant assessment criteria, which generally reflect the similar entity claimed by Khalaf (2015) against international preservation policy. The missing general assesment features are (i) the parameter to evaluate the minimum acceptance of the changes and (ii) the need of a new framework in measuring the value of aesthetic element and cultural element in architecture.

\section{ANALYSIS AND DISCUSSION}

\subsection{The parameter of minimum acceptance and the rational outstanding expectation in sustaining cultural identity}

The respondents' opinions suggest that the parameter scale that is currently implemented for measuring subjective indicator requires further improvement to measure minimum acceptance and rational outstanding expectation. The indicator of the assessment needs to project a refined interpretation of the need and function of cultural elements for the current social life style and twenty-first-century design constrain. Despite the cultural value, the current design value implemented in sustainable architecture can be coherently integrated with the BEA tools, which are considered appropriate for responding to the current design constrain. Therefore, a comprehensive study is required to identify a refined design element for a rational outstanding expectation in bridging traditional elements with modern elements. The respondents'comments also appear to imply that their unresponsiveness to the recommendation by Kinahan (2013) towards HIA which comand for false interpretaion by professional (as mentioned in section 2). Both respondents also indicated that the existing local policies are not sufficient to facilitate developing a new assesment tool for controlling new developments in cultural context.

R1:. '..the assessment should commence with a study to integrate, until what extend a modern element is acceptable to be built in cultural context and until what extend a cultural element is expected to be built in modern context? For an example we cannot expect new house to be built using natural element due to economic and source constrain. While using a typical modern material technology shall fasten the construction work..'

R2: '..the assessment is actually missing a study to refine the value of cultural elements for the current usage..'

\subsection{The need of a new framework for measuring the value of aesthetic element and cultural element in architecture}

The respondents also addressed a few aspects that need to be thoroughly assessed in terms of cultural values, which differ from the focus in the current NAIP and MIAKB. Cultural values underlying traditional architecture are greatly derived from building, aesthetic, and cultural elements. The BEA tools, nevertheless, focus on the design value of new technology and system found on a building element. This feature leads to a typical design value that lacks notable a cultural value that adheres to the design concept of traditional architecture. Although the twenty-first design constrains have impeded adopting a design concept based on traditional architecture, it does not mean that overlooking cultural values is permitted. Aesthetic and cultural elements are greatly missing due to very limited studies being conducted on the integration of these elements into the BEA tools. These elements are also found not related to the current criteria and indicator of sustainable architecture 
concept, which focuses on building performance. Unlike the elements of traditional architecture, the aesthetic and cultural elements of a modern building are found no longer significant from the concept of sustainable and BEA tool itself. This missing element is highlighted by both respondents in relation to the missing study of measuring aesthetic and cultural elements in the architecture in Kampong Bharu or in Malay cultural context.

\begin{abstract}
R1:The quality of the cultural elements are also important to be refine as the restored elements of Traditional Malay House(TMH) currently are might only functioned for esthetic value. If the aim of sustaining the life style of the Malay cultural, the expectation of the qualities and function of the element must be interpreted in broader range. This leads to another future knowledge to improvise the efficiency assessment by refining the value of aesthetic elements and cultural elements of a specific cultural item which also has been missing in current architecture national policy.
\end{abstract}

R2: This is also supported by current knowledge whereby very limited studies are lacking to investigate the precise value of varies aesthetic element and cultural element contained in TMH, and the minimum value of this elements which expected to be preserved in new residential building.

The respondents' comments suggest that in order to respond to the research gap in evaluating cultural value, we must consider the related elements that bond to cultural value. Cultural value is actually derived from the integration of three (3) general elements, namely (i) building element, (ii) aesthetic element, and (iii) cultural element. Building element is the typical physical element usually found in any building, such as building envelope and spaces (Naziaty Mohd. Yaacob \& Megat Ariff Shah Megat, 2007; Pallasmaa, 2011; Shiner, 2011; Venturi, 1977), whereas aesthetic element can be interpreted as the cultural image of a building, which is usually presented in the form of physical signs and symbols of motif and decorations (Arheim, 1969; Francis, 2014; Winters, 1937). Aesthetic elements are usually used to enhance the image of building elements or to act as additional design elements attached to the building elements. Aesthetic elements also provide a significant symbol to the value of social-spiritual, social-Allegorical, and social-emotional, according to cultural context (Hasbollah \& Hasif, 2014).

Cultural element, on the other hand, refers to the intangible element that motivates a cultural action to be operated accordingly to a building context. The cultural element also leads to sustaining cultural soul within a community and individual (Andalib \& Abdolahzadefard, 2013; Ettehad et al., 2014). Social-spiritual is usually related to the soul of a person in responding to the belief of cultural myths or ritual. It is also represented in a symbolic object or action (Vanclay, 2017). Allegorical value presents the symbol of the status of a person or community (Hasbollah \& Hasif, 2014), Usually, a more lavish of the aesthetic symbol presents a higher status. Emotional symbol presents the pride of a culture, such as the outstanding ideology of the cultural and skillful artisans (Jorgensen \& Stedman, 2001). By identifying the missing aesthetic and cultural elements, this review supports the notion that the assessment methodology of the BEA tool might not be sufficient to evaluate aesthetic and cultural values because the mechanisms used in the tool are unlikely to evaluate the values derived from aesthetic and cultural elements in an architecture.

\title{
4. CONCLUSION
}

This paper has drawn the necessity to improvise the current assessment framework by adopting the basic principle of assessment component offered in the BEA tools. It is also recommended that the current preservation policies be derived from studies on (i) the development of new parameters score scale for indicators and (ii) the improvement on score scale parameter for final score assessment. However, developing a new framework requires a comprehensive study to refine the value of aesthetic element and cultural element in traditional architecture as well as its rationality to be adopted in new building. Further exploratory study shall provide richer and deeper information due to the inadequacy of previous studies in recommending the entities to sustain the cultural value in new building. A new conceptual framework is also needed to generate a new way of assessing the three general elements in architecture, namely building, aesthetic, and cultural. The framework shall justify the similarity and difference among the assessment methodologies that are needed among the three architecture elements.

Meanwhile, the criteria and indicators in the new architecture policy, namely the BEA tool, offer a different type of design value compared to cultural value, which is expected from a preservation concept. The BEA tool adopts the concept of sustainable architecture as the design principle for the twenty-first-century need. The new design value derived from this tool or sustainable architecture concept shares four common design values which differ from traditional concept. These four common design values are thermal assistance, facilities management, 
pollution, and energy efficiency of active design. Some of these design values are already established in current built environment policies while some are getting attention in research development and national authority for further future needs. Thus it is important to not allow the rejection of these design values in sustaining cultural identity in new architecture. It has also been revealed that some cultural values are considered no longer relevant due to the constraints in twenty-first-century.

Thus, based on these findings, it is clear that giving priority in sustaining cultural values on new architecture is needed without rejecting the idea of new material and technologies. It is suggested thus that future research explore the views of rationale minimum acceptance and outstanding expectation in sustaining cultural elements in new architecture.

\section{ACKNOWLEDGMENTS}

The authors would like to acknowledge the financial support they received from a Postgraduate Research Grant (PG138-2014A) established at the Institute of Research Management and Consultancy (IPPP), University of Malaya.

\section{REFERENCES}

Abdul Rahman, A. R. (1999). The Traditional Malay Architectural world view (with emphasis on the role of the tukang). Journal Alam Bina, 2(1), 1-12.

Adegbile, B. O. (2013). Assessment and Adaptation of an Appropriate Green Building Rating System for Nigeria . Journal of Environment and Earth Science, 3(1), 1-11.

Agency, N. Z. T. (2014). Guide to assessing historic heritage effects for state highway projects.

Ahmad Najib, A. (n.d.). Legacies of an Urban Village Kampung Baru History. In Architectural Features and Heritage. Pertubuhan Arkitek Malaysia (PAM)

Alderson, C. R. (2006). Responding to Context: Changing Perspectives on Appropriate Change in Historic Settings, 37(4), 22-33.

Alhabshi Sharifah Mariam. (2010). Surviving Urban Renewal Program: Case Study of a Traditional Urban Village in Kuala Lumpur. Proceedings Seminar on Nasional Resilience (SNAR 2010) "Political Managements and Policies in Malaysia" , 13-15 July 2010, Bayview Hotel Langkawi. Institute of Tun Dr. Mahathir Mohamad's Thoughts, Universiti Utara Malaysia Sintok, Sintok, 227-313.

Ali, H. H., \& Al, S. F. (2009). Developing a Green Building Assessment Tool for Developing Countries - Case of Jordan. Building and Environment, 44(5), 1053-1064. Retrieved from http://dx.doi.org/10.1016/j.buildenv.2008.07.015.

Andalib, A., \& Abdolahzadefard, A. (2013). A nalysis A Development Framework for Urban Heritage Conservation Versus Development Trends in Shiraz, Iran, 3(1), 17-22.

APUDG. (2014). Draf Pelan Induk Terperinci Pembangunan Kampong Bharu.

Arheim, R. (1969). Art and Visual Perception. University of California Press Berkeley and Los Angeles.

Baird, G. (2015). Users ' Perceptions of Sustainable Buildings - Key Findings of Recent Studies. Renewable Energy, 73, 77-83. Retrieved from http://dx.doi.org/10.1016/j.renene.2014.04.004

Bernama. (2017). 15 squatter houses razed in Kampung Baru fire. Retrieved from http://www.thesundaily.my/news/2017/12/29/15-squatter-houses-razed-kampung-baru-fire-updated 
Borg, M., Borg, M., \& Thesis, D. (2001). Environmental Assessment of Materials, Components and Buildings: Building Specific Considerations, Open-loop Recycling, Variations in Assessment Results and the Usage Phase of Buildings. Assessment.

Cadw. Heritage Impact Assessment in Wales (2017). Retrieved from http://cadw.gov.wales/docs/cadw/publications/historicenvironment/20170531Heritage Impact Assessment in Wales 26917 EN.pdf

Chandler, D. D. (2007). Semiotics: the basics. Basics (Routledge (Firm), xviii, 307 p. https://doi.org/10.1016/S0378-2166(02)00176-5.

Chen, X., Yang, H., \& Lu, L. (2015). A Comprehensive Review on Passive Design Approaches in Green Building Rating Tools. Renewable and Sustainable Energy Reviews, 50, 1425-1436. Retrieved from http://www.scopus.com/inward/record.url?eid=2-s2.0-84934958424\&partnerID=tZOtx3y1

Chester, C. (2017, June 16). Experience Malay food and culture on this free Kampung Baru walk in Kuala Lumpur. The Straits Time Online.

Chetham, J. (2010). Best Practice Guidelines TANGATA WHENUA EFFECTS ASSESSMENT - a roadmap for undertaking a Cultural Impact Assessment under HSNO 1996.

Committee, F., \& on Environmental and Occupational Health, C. (2010). Heritage Impact Assessment (Vol. 2).

Council, G. B. (2013). INTERNATIONAL FRAMEWORK FOR SOCIO-ECONOMIC FACTORS FOR GREEN BUILDING RATING TOOLS IN DEVELOPING COUNTRIES. Green Building Council, (October).

Council PPKB. (2014). Laporan Analisis Maklum Balas Majlis Pelancaran \& Sesi Pameran PITPKB 2020.

Creswell, J. W. (2007). Qualitative Choosing Among Five Approaches.

DBKL. (2000). Pelan Struktur Kuala Lumpur.

Delanty, G., \& Jones, P. R. (2002). European Identity and Architecture. European Journal of Social Theory, 5(4), 453-466. https://doi.org/10.1177/136843102760514009.

Do-kyoung Kim. (2006). The natural environment control system of Korean traditional architecture : Comparison with Korean contemporary architecture. Building and Environment, 41, 1905-1907. https://doi.org/10.1016/j.buildenv.2005.07.007

Engelhardt, R. a. (2010). "First Principles" in Conservation: The UNESCO Asia-Pacific Heritage Awards. APT Bulletin, 41(2), 57-65. from http://scholar.google.com/scholar?hl=en\&btnG=Search\&q=intitle:\%22First+Principles\%22+in+Conserva tion:+The+UNESCO+AsiaPacific+Heritage+Awards\#0\%5Cnhttp://www.jstor.org/stable/20749124?origi n=JSTOR-pdf\%5Cnhttp://scholar.google.com/scholar?hl=en\&btnG=Search

Ettehad, S., Azeri, R. K., \& Kari, G. (2014). The Role of Culture in Promoting Architectural Identity. European Online Journal of Natural and Social Sciences Special Issue on Architecture, 3(4), 410-418. Retrieved fromhttp://search.proquest.com/docview/1679263178/fulltextPDF/3677979953EF48F7PQ/6?accountid=3 1562

Fowler, K. M., \& Rauch, E. M. (2006). Sustainable Building Rating Systems Summary. Contract, (July 2006), 155 .

Francis, D. K. C. (2014). Architecture Form, Space, and Order. John Wiley \& Sons.

Gunlu, E., Pirnar, I., \& Yagc1, K. (2009). Preserving cultural heritage and possible impacts on regional development: Case of Izmir. International Journal of Emerging ..., 1, 13. Retrieved from 
http://www.regionalstudies.org/uploads/networks/documents/tourism-regional-development-and-publicpolicy/gunlu.pdf

Harold, B., Abdul Samad, H., \& Zaharah, M. (2012). The Village in the City. Economic \& Political Weekly (Vol. 47). Singapore Oxford University Press 1991. https://doi.org/10.15957/j.cnki.jjdl.2014.06.016

Harrell, M. C., \& Bradley, M. A. (2009). Data Collection Methods Semi-Structured Interviews and Focus Groups. RAND Corporation.

Hasbollah, \& Hasif, R. (2014). A Theoretical Framework for Conservinig Cutural Values of Heritage Building in Malaysia From the Perspective of Facilities Managament. (Doctoral dissertation, University of Salford).

Hosseini, E., Mursib, G., \& Shahedi, B. (2011). Augmentation of Cultural Identity and Architectural Innovation, (May).

Hosseini, E., Mursib, G., \& Shahedi, B. (2012). Values in Traditional Architecture : Malay House, (April).

Harold, B., Abdul Samad, H., \& Zaharah, M. (2012). The Village in the City. Economic \& Political Weekly (Vol. 47). Singapore Oxford University Press 1991. https://doi.org/10.15957/j.cnki.jjdl.2014.06.016

Ibrahim, H. G. A. (2016). Regeneration of sustainability in Contemporary Architecture : Approach Based on Native Function and Activities to Strengthen Identity. In Urban Planning and Architecture Design for Sustainable Development, UPADSD 14- 16 October 2015 Regeneration (Vol. 216, pp. 800-809). Elsevier B.V. https://doi.org/10.1016/j.sbspro.2015.12.077.

Imam, S. (2013). ASSESSMENT AND REVIEW OF INFILL DESIGNS' GUIDELINES FOR RESIDENTIAL URBAN CONSERVATION AREAS. International Journal for Housing Science, 37(3), 137-149.

Incorporated George Town World Heritage. Draft Guidelines for the Preparation of Heritage Impact Assessment ( HIA ) World Heritage Cities of Melaka and Georgetown (2012).

J.Ostwald, M., \& Fleming, S. (2000). Movements in Twentieth Century Architecture. University of Newcastle, Australia.

Jarod, L. (2015, May). Kampung Baru does its part to preserve Malay heritage amid modernisation. Retrieved from https:/www.thestar.com.my/metro/focus/2015/05/04/village-in-the-heart-of-the-city-kampungbaru-does-its-part-to-preserve-malay-heritage-amid-modernis/

Jencks, C. (1987). The Language of Post Modernism. London: Academy Editions 1987..

Jencks, C. (1990). The New Moderns: From Late to Neo- Modernism. New York: Rizzoli,1990..

Joibi, N. (2014). Fire destroys two rows of squatter houses in Kampung Baru. Retrieved from https://www.thestar.com.my/news/nation/2014/12/15/squatter-houses-in-kampung-baru-razed/

Jorgensen, B. S., \& Stedman, R. C. (2001). Sense of Place As an Attitude: Lakeshore Owners Attitudes Toward Their Properties. Journal of Environmental Psychology, 21(3), 233-248. https://doi.org/10.1006/jevp.2001.0226

Ju, S. R., Omar, S., \& Ko, Y. E. (2012). Modernization of the Vernacular Malay House In Kampong Bharu , Kuala Lumpur, (May), 95-102.

Julaihi Wahid, H. M. (2000). Images of Architecture and Planning in Malaysia; The Quest for Identity Revisited. School of Housing Building and Planning,Universiti Sains Malaysia.

K.C.Ding, G. (2008). Sustainable Construction -The Role of Environmental Assessment Tools. Journal of Environmental Management, 86(3), 451-464. 
Kamberelis, G., \& Dimitriadis, G. (2005). Focus Groups: Strategic Articulations of Pedagogy, Politics, and Inquiry. In The Sage handbook of qualitative research (pp. 887-907). Sage Publications Ltd.

Khalaf, R. W. (2015). The Reconciliation of Heritage Conservation and Development: The Success of Criteria in Guiding the Design and Assessment of Contemporary Interventions in Historic Places. International Journal of Archietctural Research, 9(1), 77-92.

Khalil, N. (2013). Literature Review on the Concept of Building Performance and Incorporation of Users ' Feedback, (February).

Khalil, N., Kamaruzzaman, S. N., Nawawi, A. H., Husin, H. N., \& Hashim, A. E. (2015). The Conceptual Framework of Building Performance-Risk Indicators (PRI) for Buildings Users in Higher Education Institutions. Applied Mechanics and Materials, 747(September), 363-366. https://doi.org/10.4028/www.scientific.net/AMM.747.363

Lasalle, J. L. (2008). Green Building Rating Systems : Going Beyond the Labels - October 2008. Jones Lang Lasalle IP,INC 2008, (October).

Mara, N., West, S., Victoria, P., Travers, I., Manager, P., \& Johnston, C. (2012). Cultural Heritage and Social Values Assessment Volume 1 : Heritage Places, Connections \& Values (Vol. 1).

Mari Anna Fujita. (2010). Forays into Building Identity: Kampung to Kampong in the Kuala Lumpur Metropolitan Area. Journal of Architectural Education, 63(2), 8-24.

Mcgill, G., Oyedele, L. O., Mcallister, K., \& Qin, M. (2015). Effective indoor air quality for energy-efficient homes : a comparison of UK rating systems, 8628(December). https://doi.org/10.1080/00038628.2015.1078222.

Misırlısoy, D. (2017). New Designs in Historic Context: Starchitecture vs Architectural Conservation Principles. Journal of Civil Engineering and Architecture, 5(6), 207-214. https://doi.org/10.13189/cea.2017.050602

Moser, S. (2012). Circulating Visions of 'High Islam': The Adoption of Fantasy Middle Eastern Architecture in Constructing Malaysian National Identity. Urban Studies, 49(13), 2913-2935. https://doi.org/10.1177/0042098012452453

Nezhad, S. F., Eshrati, P., Eshrati, D., \& Design, E. (2015). A Definition of Authenticity Concept in Conservation of Cultural, 9(1), 93-107

Nguyen, B. K. (2011). Tall-building Projects Sustainability Indicator. University of Sheffield.

Nguyen, B. K., \& Altan, H. (2011). Comparative review of five sustainable rating systems. Procedia Engineering, 21(0), 376-386. Retrieved from http://dx.doi.org/10.1016/j.proeng.2011.11.2029

Nik, M. F. (2014). Garis Panduan Senibina Melayu Islam Kampong Bharu. PPKB..

Nikolaou, T., Kolokotsa, D., \& Stavrakakis, G. (2015). Advances in Building Energy Research Review on methodologies for energy benchmarking, rating and classification of buildings Review on methodologies for energy benchmarking , rating and classification of buildings, 2549(December). https://doi.org/10.1080/17512549.2011.582340

NZTA. (2015). Historic heritage impact assessment guide for state highway projects.

Pichedpan. (2011). Visual Signification and Postmodernity in Thai Print Advertising. In The Asian Conference on Media and Mass Communication Official Conference Proceedings 2011 (pp. 106-117).

Plasma, J. (2011). The Embodied Image: Imagination and Imagery in Architecture. John Wiley \& Sons, Ltd, Publication. 
Putting the New into Kampong Bharu. (2004). The New Straits Times.

Rasdi, M. T. M. (2011). Krisis Pemikiran SeniBina Malaysia. UTM, Skudai, Johor Bahru.

Reed, R., Bilos, A., \& Wilkinson, S. (2009). International Comparison of Sustainable Rating Tools Authors. Journal of Sustainable Real Estate, 1(1), 1-22.

Ryberg-Webster, S., \& Kinahan, K. L. (2013). Historic Preservation and Urban Revitalization in the Twenty-first Century. Journal of Planning Literature, 29(2), 119-139.

Salleh Buang. (2007). Malaysian Torrens System. Kuala Lumpur: Dewan Bahasa dan Pustaka.

Samsor Junet. (2004). Masa Majukan Kampong Bharu.

Saradj, F. M. (2015). C OMPATIBLE DEVELOPMENT SOLUTIONS IN THE CONTEXT OF. Urbanism, 7(4), $285-300$

Shaawat, M. E., \& Jamil, R. (2014). a Guide To Environmental Building Rating System for Construction of New Buildings in Saudi Arabia. Emirates Journal for Engineering Research, 19(2), 47-56.

Shamsul, A. B. (1996). Debating about identity in Malaysia: A discourse analysis. Southeast Asian Studies, 34(3), 476-499.

Sharifi, A. (2013). Sustainability at the neighborhood level: assessment tools and the pursuit of sustainability, 233. Retrieved from https://nies.academia.edu/AyyoobSharifi

Shiner, L. (2011). On aesthetics and function in architecture: The case of the "spectacle" art museum. Journal of Aesthetics and Art Criticism, 69(1), 31-41. https://doi.org/10.1111/j.1540-6245.2010.01444.x.

Silva;, A. T., \& Roders, A. P. (2011). Cultural Heritage Management and Heritage ( Impact ) Assessments, 1999, $375-382$

Snowball, J. D., \& Courtney, S. (2010). Cultural heritage routes in South Africa: Effective tools for heritage conservation and local economic development? Development Southern Africa, 27(4), 563-576. https://doi.org/10.1080/0376835X.2010.508589

Sotoudeh, H., \& Abdullah, W. M. Z. W. (2013). Evaluation of fitness of design in urban historical context: From the perspectives of residents. Frontiers of Architectural Research, 2(1), 85-93. https://doi.org/10.1016/j.foar.2012.10.007

Stern, R. A. M. (1988). What the Classical can do for the Modern. London: Academy Editions.

Steven W. Semes, \& Chair, K. R. (2007). Sense of Place: Design Guidelines for New Construction in Historic Districts.

Suleiman, M. (1999). Transformasi Sosial Melayu Bandar: Satu Kajian Kes di Kampong Bharu. Jabatan Persuratan Meayu, Universiti Kebangsaan Malaysia.

Surat, M., Tahir, M. M., Tawil, N. M., Ismail, R., Usman, I. M. S., Che-Ani, a I., ... Md. Nor, M. F. I. (2010a). Re-evaluating the Idea of a Malaysian Architectural Identity Towards a Sustainable Environment. EE'10 Proceedings of the 5th IASME/WSEAS International Conference on Energy \& Environment, (January), 25-30

Surat, M., Tahir, M. M., Tawil, N. M., Ismail, R., Usman, I. M. S., Che-Ani, a I., ... Md. Nor, M. F. I. (2010b). Re-evaluating the Idea of a Malaysian Architectural Identity Towards a Sustainable Environment. EE'10 Proceedings of the 5th IASME/WSEAS International Conference on Energy \& Environment, 25-30. 
The Government of the Hong Kong Special Administrative Region. (2009). Heritage Impact Assessment Mechanism for Capital Works Projects.

Tim, B. (1986). Kampung Rules: Landscape and the Contested Government of Urban(e) Malayness. Urban Studies, 39(9), 1685-1701. https://doi.org/10.1080/0042098022015172.

Tobias, O. N., Kerrie, W., Christina, J. D., \& Nibedita, M. (2018). The use of focus group discussion methodology: Insights from two decades of application in conservation. Methods in Ecology and Evolution. Retrieved from file:///C:/Users/DELL/AppData/Local/Packages/Microsoft.MicrosoftEdge_8wekyb3d8bbwe/TempState/ Downloads/O.Nyumba_et_al-2018-Methods_in_Ecology_and_Evolution (1).pdf.

Tomaselli, K. (2009). Appropriating Images: The Semiotics of Visual Representation. Left Coast Press, Inc. (January 1, 1999).

Tweed, C., \& Sutherland, M. (2007). Built cultural heritage and sustainable urban development. Landscape and Urban Planning, 83, 62-69.

Ujang, N. (2012). Place Attachment and Continuity of Urban Place Identity, 49, $156-167$. https://doi.org/10.1016/j.sbspro.2012.07.014

Ujang, N. (2016). Transforming the Historical Urban Village of Kampong Bharu Into a New Urban Centre in Kuala Lumpur. Retrieved from https://malaysiacities.mit.edu/paperUjang

Vanclay, F. (2017). SIA principles Assessment. Impact Assesment and Project Appraisal, 5517(November). https://doi.org/10.3152/147154603781766491

Venturi, R. (1977). Contradiction in Architecture. New York. https://doi.org/10.1080/10464883.2012.714912

Wallbaum, H., Ostermeyer, Y., Salzer, C., \& Escamilla, E. Z. (2012). Indicator based sustainability assessment tool for affordable housing construction technologies. Ecological Indicators, 18, 353-364.

Wan Hazmir, B., Norfatimah, A., Sharifah Salwa, S. A., \& Faizatul Farlin, F. K. (2004). PM bimbang kepadatan penduduk Kampung Baru. Berita Harian.

Winters, N. B. (1937). Architecture is Elementary: Visual Thinking Through Architectural Concepts.

Wolf, H. V. (2016). Identity in Malaysia - Public Reception and Communal Practice. Journal of Education and Social Science, 3(1982), 21.

Yaacob, N. M., \& Omar, M. A. S. M. (2007). Finding form and missing space : Malaysian architecture identity. In In Asian Coalition for Architecture and Urbanism Workshop (3-4 Jul 2007 : Kuala Lumpur).

Yuan, L. J. (2002). The Traditional Malay House. Institut Masyarakat. Retrieved from elawmalaysia@igc.apc.org 